\title{
REVIEW
}

\section{Evolution of the Thyroid Hormone-Binding Protein, Transthyretin}

\author{
D. M. Power,* N. P. Elias, $\nmid$ S. J. Richardson, $\neq$ J. Mendes, $\dagger$ C. M. Soares, $\uparrow$ \\ and C. R. A. Santos* \\ * Centro de Ciências de M AR (CCM AR), Universidade do Algarve, Campus de Gambelas, 8000 Faro, Portugal; \\ †Instituto de Tecnologia Química e Biológica, U niversidade N ova de Lisboa, Oeiras, Portugal; and \\ ¥Russell Grimwade School of Biochemistry, U niversity of M elbourne, M elbourne, Victoria, Australia
}

Accepted May 12, 2000

Transthyretin (TTR) belongs to a group of proteins, which includes thyroxine-binding globulin and al bumin, that bind to and transport thyroid hormones in the blood. TTR is also indirectly implicated in the carriage of vita$\min A$ through the mediation of retinol-binding protein (RBP). It was first identified in 1942 in human serum and cerebrospinal fluid and was formerly called prealbumin for its ability to migrate faster than serum albumin on electrophoresis of whole plasma. It is a single polypeptide chain of 127 amino acids $(14,000 \mathrm{Da})$ and is present in the plasma as a tetramer of noncovalently bound monomers. The major sites of synthesis of TTR in eutherian mammals, marsupials, and birds are the liver and choroid plexus but in reptiles it is synthesised only in the choroid plexus. The observation that TTR is strongly expressed in the choroid plexus but not in the liver of the stumpy-tailed lizard and the strong conservation of expression in the choroid plexus from reptiles to mammals have been taken as evidence to suggest that extrahepatic synthesis of TTR evolved first. The identification and cloning of TTR from the liver of an amphibian, Rana catesbeiana, and a teleost fish, Sparus aurata, and its absence from the choroid plexus of both species suggest an alternative model for its evolution. Protein modelling studies are presented that demonstrate differences in the electrostatic characteristics of the molecule in human, rat, chicken, and fish, which may explain why, in contrast to TTR from human and rat, TTR from fish and birds preferentially binds triiodo-L-thyronine. O 2000 Academic Press

Key W ords: distribution and function; evolution; structure; transthyretin; thyroid hormones.

\section{THYROID GLAND AND HORMONES}

Thyroid hormones (TH) have been identified in the plasma of all groups of vertebrates; they are pluripotent and are involved in growth, differentiation, metamorphosis, reproduction, hibernation, and thermogenesis. The basic unit of all vertebrate thyroid glands has been conserved throughout evolution and consists of a follicle, formed by a single layer of epithelial cells enclosing a fluid-filled space or "colloid." The follicle traps inorganic iodide, which is incorporated into thyroid hormone precursors, which are stored in the colloid. The organisation of the gland is characteristic for each vertebrate group; in mammals the thyroid is composed of two lobes connected by an isthmus across the ventral surface of the trachea; birds have two isolated, rounded lobes lying on either side of the trachea; in snakes and turtles there is a single discoid structure located anterior to the heart; the amphibian thyroid is bipartite; and in most bony fish there is no organised gland and the follicles are scattered singly 
or in small groups in the loose connective tissue of the pharynx (Bentley, 1998; Gorbman et al., 1983). Thyroid-like hormones are also apparently synthesised by nonfollicular tissue in the endostyle of protochordates and urochordates (Barrington, 1962; Monaco et al., 1981; Thorndyke, 1978; Dunn, 1980).

TH have a common chemical structure (Fig. 1) consisting of a hydrophobic thyronine nucleus, which accounts for their poor water solubility, a hydrophilic hydroxyl group attached to the phenolic ring and four iodines in positions $3,5,3^{\prime}$, and $5^{\prime}$ in thyroxine $\left(\mathrm{T}_{4}\right)$ and three similarly at 3,5 , and $3^{\prime}$ in triiodo-l -thyronine $\left(\mathrm{T}_{3}\right)$. Inactivation of $\mathrm{TH}$ occurs by the mediation of iodothyronine-deiodinase, resulting in deiodination of the inner ring and production of a series of inactive metabolites e.g. reverse $\mathrm{T}_{3}$, di, and monoiodothyronine, as well as totally unsubstituted thyronine. $\mathrm{T}_{4}$ is the main secreted product of the vertebrate thyroid gland and deiodination of its outer ring (ORD) produces the more active triiodo-l -thyronine $\left(\mathrm{T}_{3}\right)$, which has a much higher affinity for the thyroid hormone receptors (Leonard and Visser, 1986; Darras et al., 1998).

\section{THYROID HORMONE-BINDING PROTEINS}

The synthesis and secretion of thyroid hormones appear to be similar in all vertebrates studied. Thyroid hormones are stored bound to thyroglobulin in the follicular colloid. Hydrolysis of iodothyroglobulin in the epithelial cell layer liberates principally $\mathrm{T}_{4}$, which diffuses into the surrounding capillaries and rapidly partitions into lipid membranes (Dickson et al., 1987; Eales, 1985; Hillier, 1970). To counteract this effect and ensure an even distribution of thyroid hormones in perfused tissues (Mendel et al., 1987, Mendel and Weisiger, 1990), $T_{3}$ and $T_{4}$ are generally transported in the blood bound to serum proteins (Larsson et al., 1985; Robbins and Edelhoch, 1986). In the blood of larger mammals three main blood plasma thyroid hormone-binding proteins have been identified-thyroxine-binding globulin (TBG), transthyretin (prealbumin, TTR), and serum albumin (ALB) (Larsson et al., 1985) - and their binding characteristics have been determined (see Table 1). In humans TBG is present in the circulation at lower concentrations than other
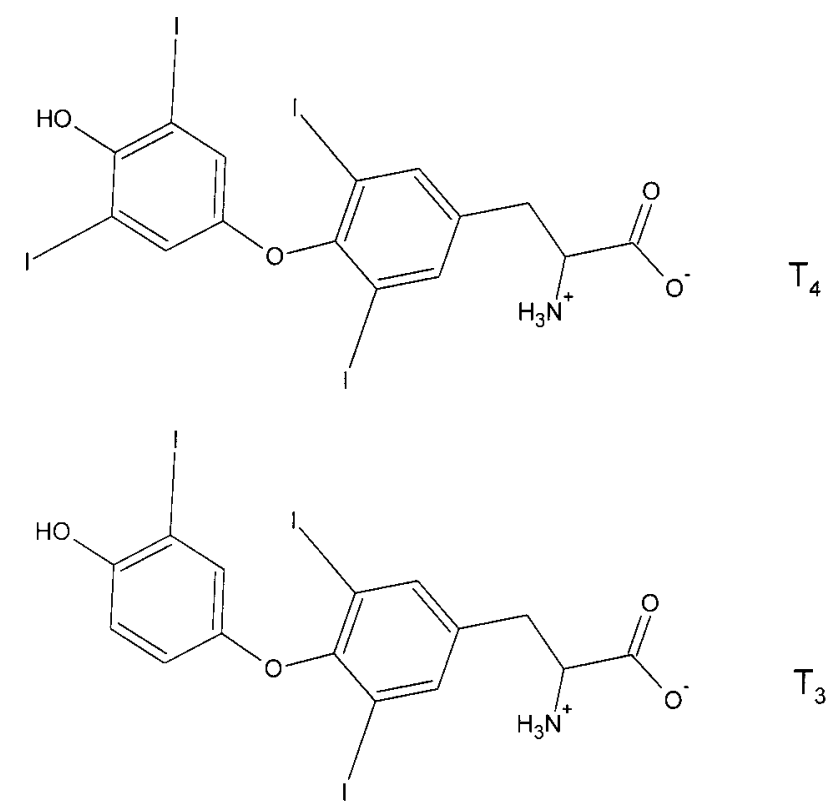

$\mathrm{T}_{3}$

FIG. 1. The structure of the thyroid hormones, $T_{4}$ (top) and $T_{3}$ (bottom).

binding proteins; nevertheless it carries about $75 \%$ of all plasma $\mathrm{T}_{4}$ as a consequence of its greater affinity for the hormone (100-fold higher; Robbins and Edelhoch, 1986). In rodents TTR is the major carrier of $T_{4}$ and in birds both TTR and ALB are carriers. There are relatively few studies of thyroid hormone-binding proteins in lower vertebrates. Moreover the results from such studies appear contradictory (Larsson et al., 1985; Richardson et al., 1994; Tanabe et al., 1969). In one study radiolabelled $\mathrm{T}_{4}$ was incubated with plasma from adult reptiles, amphibia, and fish and the resulting products were subsequently fractionated by SDSPAGE followed by autoradiography. Only one protein, ALB, bound the radiolabeled $\mathrm{T}_{4}$ (Richardson et al., 1994) and it has been proposed that this protein is the principal thyroid hormone-binding protein in the blood of such organisms. The identification in salmon of thyroid hormone-binding proteins with characteristics similar to transthyretin (Larsson et al., 1985) and the recent isolation of TTR and its cDNA from amphibian tadpoles before the metamorphic climax (Rana catesbeiana, Yamauchi et al., 1993, 1998) and from the teleost fishes sea bream (Santos and Power, 1996, 1999) and masu salmon (Oncorhychus masu) prior to smoltification (Yamauchi et al., 1999) suggest that it may also have a role in transporting $\mathrm{TH}$ in these species. Since 


\section{TABLE 1}

Principal Characteristics of Plasma Proteins Involved in the Transport of Thyroid Hormone in Humans

\begin{tabular}{lcccc}
\hline Binding protein & $\begin{array}{c}\text { Serum } \\
\text { concentration } \\
(\mathrm{mg} / \mathrm{liter})\end{array}$ & $\begin{array}{c}\text { Binding capacity } \\
(\mu \mathrm{g} / \text { liter plasma })\end{array}$ & $\begin{array}{c}\text { Relative affinity } \\
\text { for T4 and }(/) \mathrm{T} 3\end{array}$ & $\begin{array}{c}\text { Molecular weight of } \\
\text { binding protein } \\
(\mathrm{kDa})\end{array}$ \\
$\begin{array}{c}\text { chains in each } \\
\text { binding protein } \\
\text { molecule }\end{array}$ \\
$\begin{array}{l}\text { Thyroxine binding globulin } \\
\text { (TBG) }\end{array}$ & 15 & 200 & $100 / 9.0^{a}$ & 54 \\
Transthyretin (TTR) & 300 & 2300 & $100 / 9.2^{b}$ & 54 \\
Albumin (ALB) & 45,000 & 100 & $100 / 49.0^{c}$ & 66 \\
\hline
\end{tabular}

Note. $K_{\mathrm{A}}$ is the affinity constant. Table adapted from de la Paz et al. (1992).

${ }^{a}$ Snyder et al. (1976): $K_{\mathrm{A}} \mathrm{T}_{4}=2.5 \times 10^{9} \mathrm{M}^{-1}$.

${ }^{b}$ Andrea et al. (1980): $K_{\mathrm{A}} \mathrm{T}_{4}=3.5 \times 10^{7} \mathrm{M}^{-1}$.

${ }^{c}$ Sterling (1964): $K_{\mathrm{A}} \mathrm{T}_{4}=5.0 \times 10^{5} \mathrm{M}^{-1}$.

in teleost fish and amphibia, TTR appears to have a higher affinity for $\mathrm{T}_{3}$ than for $\mathrm{T}_{4}$ (Yamauchi et al., 1993, 1999), the contradictory observations mentioned earlier may be explained by suggesting that albumin may be the principal $\mathrm{T}_{4}$-binding protein and TTR the principal $\mathrm{T}_{3}$-binding protein. The relative importance of these two thyroid hormone-binding proteins at different stages of the life cycle of different organisms remains to be determined, particularly as earlier studies were carried out with plasma samples from adult teleost fish (Richardson et al., 1994) while more recent studies have been carried out with samples from juvenile teleost fish (Santos and Power, 1996, 1999; Yamauchi et al., 1993, 1998, 1999). The identification of TTR in fish other than teleosts and the characterisation of its function will be important in defining its role in $\mathrm{TH}$ transport in fish. Throughout this review the term fish indicates teleosts, the only group from which this protein and its gene have been characterized.

\section{TRANSTHYRETIN - CHEMISTRY AND STRUCTURE}

The chemistry and structure of human TTR are well characterised because of its stability and rela- tive abundance, rendering it easy to purify in sufficient quantities for study. Moreover, its importance in a human disease, familial amyloidotic polyneuropathy (FAP), has also provided further incentive for study. There is an abundance of structural studies of this protein in humans and mouse but few in other species.

\section{Molecular Structure}

TTR is a 127-residue monomer that has been shown, in human and chicken, to function in the form of a 55-kDa tetramer composed of four identical subunits. The resolution of the crystal structure of human, chicken, and rat TTR has been determined at 1.8 AA (Blake et al., 1974, 1978; Wojtczak et al., 1992; Hamilton et al., 1993), $2.9 \AA \AA$ A (Sunde et al., 1996), and $2.5 \AA A$ (Wojtczak, 1997), respectively. Moreover, X-ray diffraction indicates that the dominant secondary structure is the $\beta$-sheet. Such studies have revealed that the functional tetramer contains two binding sites that are structurally identical and are deeply buried in a narrow cylindrical channel that runs through the centre of the protein molecule. The amino acids that are thought to be in-

FIG. 2. Multiple sequence alignment carried out using Clustal X (Gibson et al., 1994) of transthyretin with the prepeptide from representative species of all vertebrate groups: human (Sasaki et al., 1985), pig (Sus scrofa, Duan et al., 1995), rat (Rattus norvegicus, Dickson et al., 1985), dunnart (Sminthopsis macroura, Duan et al., 1995), wallaby (Macropus eugenii, Brack et al., 1995), opossum (Monodelphis domestica, Duan et al., 1995), chicken (Gallus gallus, Duan et al., 1991), skink (Tiliqua rugosa, Achen et al., 1993), frog (Rana catesbeiana, Yamauchi et al., 1998), and sea bream (Sparus aurata, Santos and Power, 1999). Coloured blocks refer to the physiochemical properties of the amino acids according to the key. The underlined residues correspond to the region modelled. Residues marked with an asterisk are identical in all species analysed. 


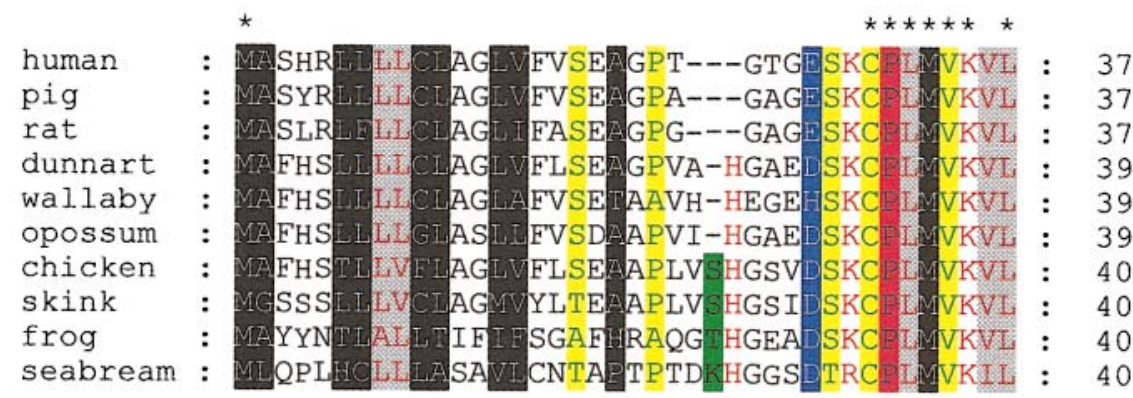

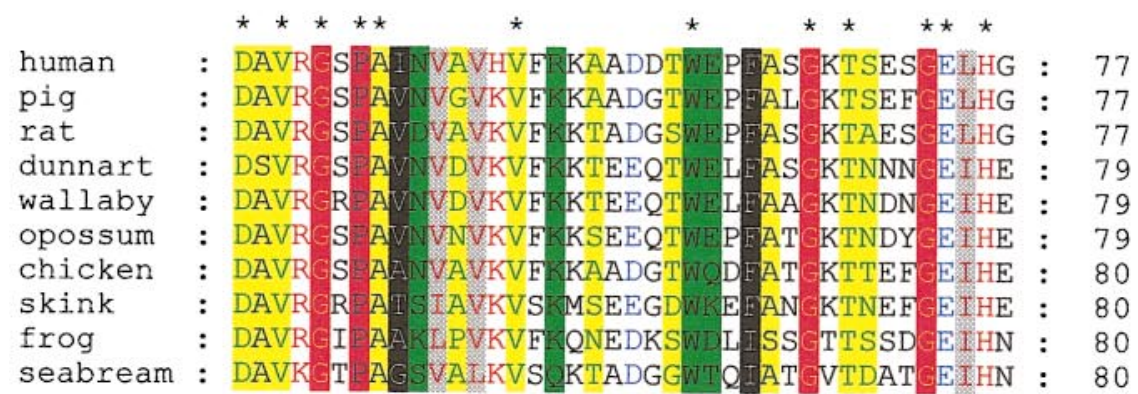

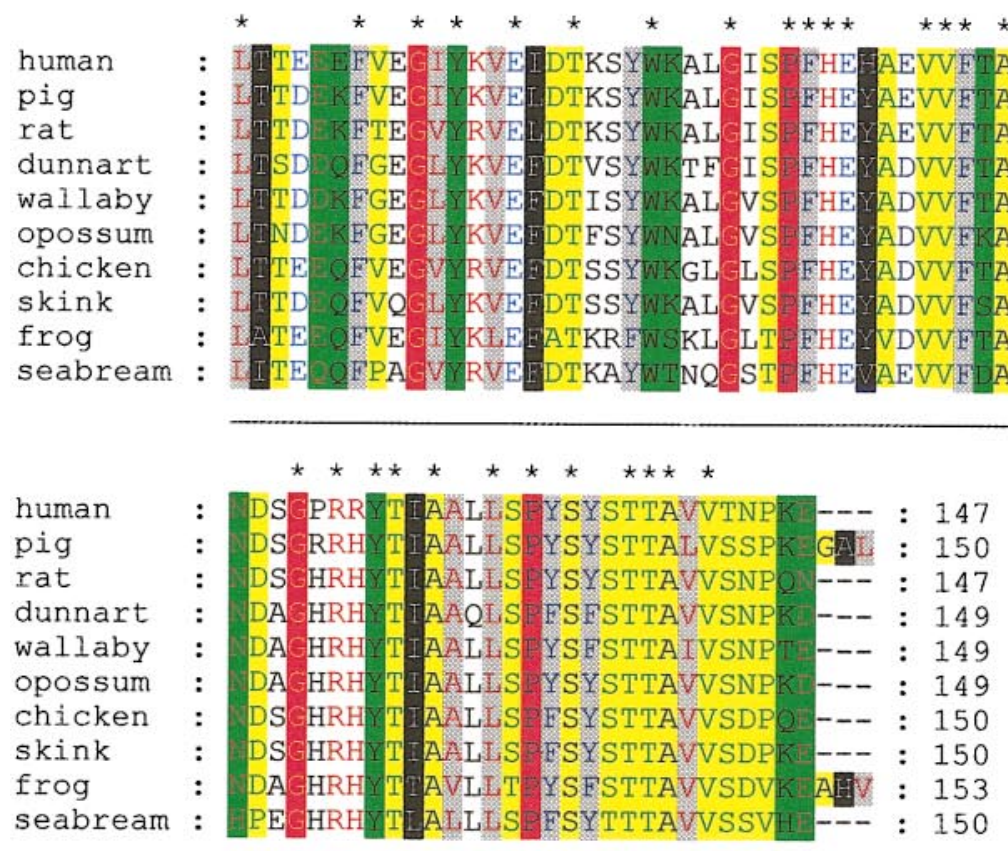

Physiochemical properties coloured key (X-amino acid):

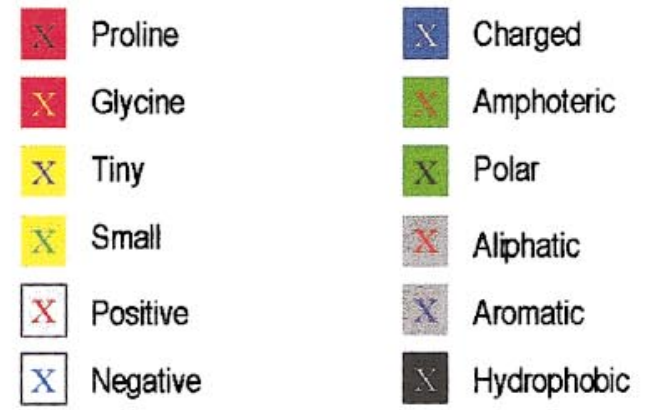




\section{言言}

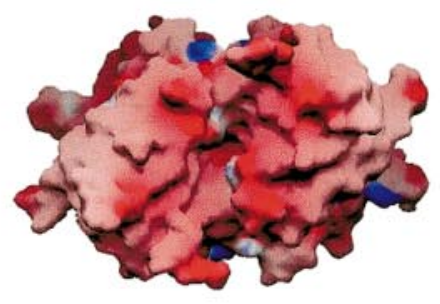

뭉

음

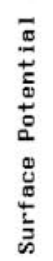
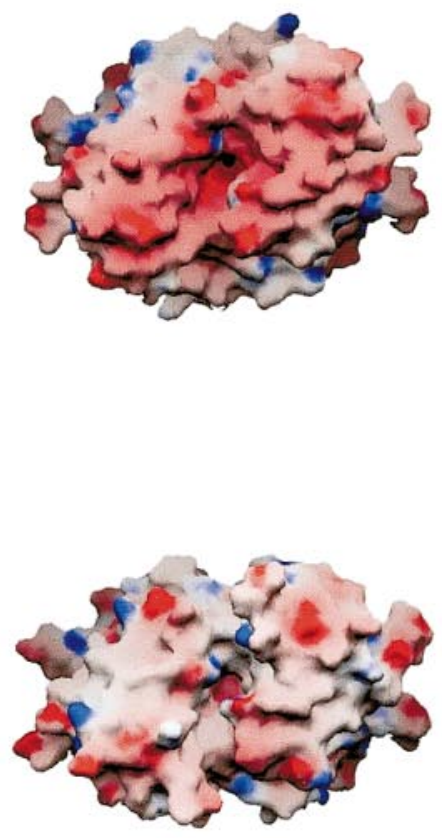
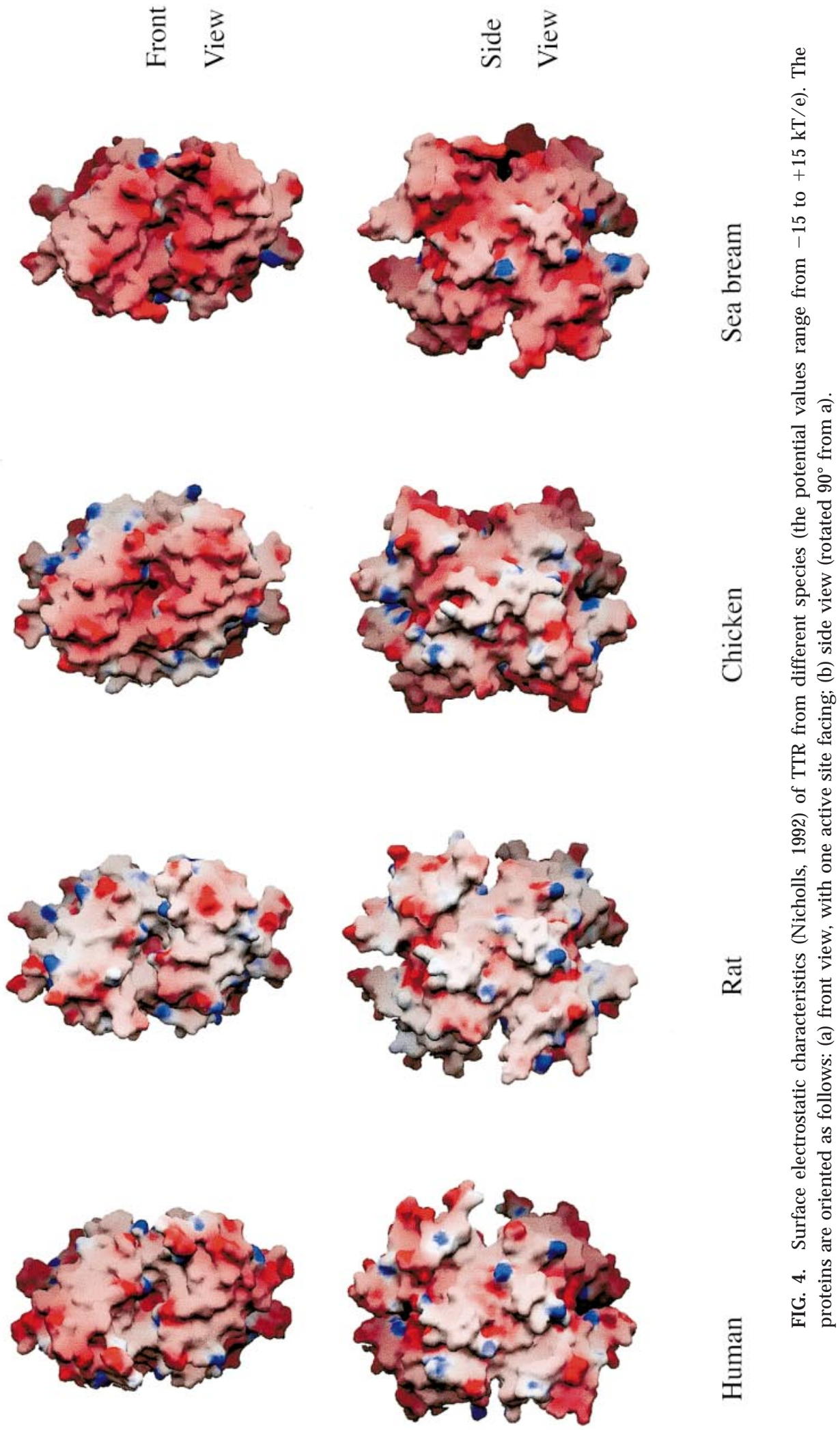


\section{TABLE 2}

Sequence Identity (First Line of Each Row, \%) and Similarity (Second Line of Each Row, \%) Based on Clustal X (Gibson et al., 1994) Alignments between Transthyretins from Eutherian Mammals-Human (Sasaki et al., 1985), Pig (Sus scrofa, Duan et al., 1995), and Rat (Rattus norvegicus, Dickson et al., 1985); Marsupial Mammals—Dunnart (Sminthopsis macroura, Duan et al., 1995) (Australian Polyprotodonta), Wallaby (Macropus eugenii, Brack et al., 1995) (Australian Dyprotodonta), and Opossum (Monodelphis domestica, Duan et al., 1995) (American Polyprotodonta); Birds-Chicken (Gallus gallus, Duan et al., 1991); Reptiles-Skink (Tiliqua rugosa, Achen et al., 1993); Amphibians-Frog (Rana catesbeiana, Yamauchi et al., 1998); and Fish-Sea Bream (Sparus aurata, Santos and Power, 1999)

\begin{tabular}{|c|c|c|c|c|c|c|c|c|c|}
\hline & Pig & Rat & Dunnart & Wallaby & Opossum & Chicken & Skink & Frog & Sea bream \\
\hline \multirow[t]{2}{*}{ Human } & 85 & 82 & 70 & 69 & 70 & 73 & 66 & 62 & 48 \\
\hline & 92 & 92 & 85 & 81 & 83 & 86 & 84 & 67 & 67 \\
\hline \multirow[t]{2}{*}{ Pig } & & 84 & 71 & 71 & 73 & 73 & 68 & 54 & 48 \\
\hline & & 91 & 84 & 80 & 84 & 85 & 83 & 68 & 66 \\
\hline \multirow[t]{2}{*}{ Rat } & & & 72 & 71 & 72 & 74 & 67 & 51 & 52 \\
\hline & & & 87 & 82 & 85 & 85 & 84 & 67 & 70 \\
\hline \multirow[t]{2}{*}{ Dunnart } & & & & 83 & 82 & 74 & 71 & 54 & 48 \\
\hline & & & & 91 & 92 & 87 & 86 & 73 & 67 \\
\hline \multirow[t]{2}{*}{ Wallaby } & & & & & 83 & 72 & 70 & 54 & 47 \\
\hline & & & & & 87 & 83 & 84 & 71 & 64 \\
\hline \multirow[t]{2}{*}{ Opossum } & & & & & & 74 & 72 & 54 & 49 \\
\hline & & & & & & 88 & 86 & 72 & 68 \\
\hline \multirow[t]{2}{*}{ Chicken } & & & & & & & 79 & 57 & 55 \\
\hline & & & & & & & 90 & 73 & 70 \\
\hline \multirow[t]{2}{*}{ Skink } & & & & & & & & 53 & 52 \\
\hline & & & & & & & & 67 & 68 \\
\hline \multirow[t]{2}{*}{ Frog } & & & & & & & & & 47 \\
\hline & & & & & & & & & 64 \\
\hline
\end{tabular}

volved in $\mathrm{T}_{4}$ binding appear to have been conserved between the human and the chicken TTR (Duan et al., 1991) and two identical binding sites for T4 and T3 are buried deep in the central channel. The chemistry of the channel is characterised by three elements arranged linearly along it: (1) a hydrophilic patch formed by the hydroxyls of Ser 117 and Thr $119,(2)$ a hydrophobic patch formed by the methyl groups of the Leu 17, Thr 106, Ala 108, Leu 110, Thr 119, and Val 121 pairs; and (3) a group of charged residues including the paired side chains of Lys 15, Glu 54, and His 56 (Blake and Oatley, 1977). The proximity of the paired side chains of Leu 110, Ser 115, and Ser 117 causes a marked local constriction.

A model of the three-dimensional structure of bullfrog (R. catesbeiana) TTR has been reported in which the crystal structure coordinates of chicken TTR were used. The resulting model showed that despite differences in the primary amino acid sequence of bullfrog TTR, the three-dimensional structure is highly conserved at the thyroid hormone-binding sites and other important structural regions of the subunits (Yamauchi et al., 1998).

\section{Three-Dimensional Model of Sea Bream TTR}

A detailed model of sea bream TTR structure has been generated using the program Modeller version 4 (Sali and Blundell, 1993), together with the known X-ray structures of TTR from human (Hamilton et al., 1993) (PDB ID: 1tta), rat (Wojtczak, 1997) (PDB ID: 1gke), and chicken (Sunde et al., 1996) (PDB ID: 1tfp) and the sequence alignment (Fig. 2). The first 12 residues of the sea bream structure were not modelled since there were no relevant structural data for this region from crystallised human, rat, or chicken TTR. This approach was possible as a consequence of the high level of identity between the amino acid sequence of TTR from the species used (Table 2). Several models were generated and the best one was selected, on the basis of criteria, such as final PDF value, restraint violations, and conformational analysis performed with PROCHECK (Laskowski et al., 1993). The backbone coordinates were obtained from Modeller and since homology-based methods are not necessarily the best strategy for side chain modelling in highquality structural models (Burke et al., 1999), the side 

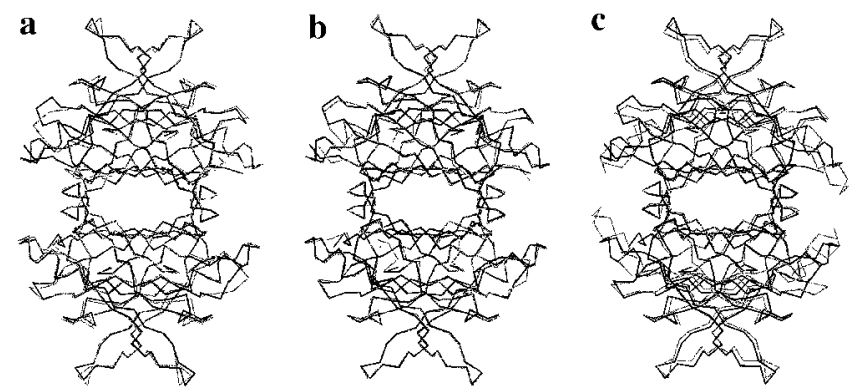

FIG. 3. Comparison between the $\alpha$-carbon tracing of the TTR structure from sea bream (solid black lines) and the known crystallographic coordinates for human, rat, and chicken (grey lines). The models were produced with Molscript (Kraulis, 1991) and Raster 3D (Merrit and Bacon, 1997). The modelled structures are viewed down the central channel with one thyroid hormone-binding site facing. (a) Comparison between sea bream and human. (b) Comparison between sea bream and rat. (c) Comparison between sea bream and chicken.

chain conformations were modelled using alternative rotamer-based techniques (Mendes et al., 1999a,b).

The structure of sea bream TTR is compared with the corresponding structures from human, rat, and chicken in Fig. 3. The modelled sea bream sequence shows greatest identity with chicken $(63.3 \%$ versus $55.0 \%$ in human) but highest similarity with human (80.0\% versus $76.6 \%$ in chicken). In common with the predicted three-dimensional structure of bullfrog TTR (Yamauchi et al., 1998) the overall topology of sea bream TTR is conserved and the predicted monomermonomer and dimer-dimer interfaces and tetrameric structure are similar to those determined by crystallography of human, rat, and chicken TTR. The modelled sea bream TTR structure shows greater similarity with those of human and rat in a defined region, amino acids 74-89, which in chicken is most dissimilar from the mammalian structure. The thyroid hormone-binding site in sea bream is also highly conserved, although Ser 117 (human sequence) is substituted by a Thr residue and given the symmetry of the tetramer, this means that there will be two substitutions per active site. This alteration may have consequences for thyroid hormone binding, as these residues are close to each other in the tetramer.

Despite the high conservation of the structures, analysis of the electrostatic properties of the TTR tetramer models (Fig. 4) shows that the surface potential, most noticeably in the thyroid hormone-binding site, is more negative in the sea bream and chicken structures (sea bream being the most negative) than in the human and rat. Although further studies are required to validate the models it is possible that the differences in electrostatic potential of TTR may be the reasons for reduced $\mathrm{T}_{4}$ binding by TTR in chicken and fish (Chang et al., 1999; Santos and Power, 1999; Yamauchi et al., 1999), since the $\mathrm{OH}$ group of $\mathrm{T}_{4}$ is predominantly ionised at physiological pH (Nilsson and Peterson, 1971), and hence negative, while in $T_{3}$ is predominantly neutral. An increased negative potential in the TTR structures of sea bream and chicken may be an unfavourable factor for $\mathrm{T}_{4}$ binding.

In humans the association constants of $\mid$-thyroxine for the two hormone-binding sites of the functional TTR tetramer differ (Table 1). The difference in affinity between the two sites, despite structural identity, has been explained in terms of a negative cooperative effect, so that the binding of ligand at one site reduces the binding affinity at the second site (de la Paz et al., 1992). This may arise from electrostatic interactions between the two molecules of the hormone when bound.

Ligand-binding studies with TTR have generally been carried out using compounds structurally similar to $\mathrm{T}_{4}$, such as the fluorescent probes 8-anilinonaphthalene-1-sulphonate (Cheng et al., 1977) and 1-dimethylaminonaphthalene-5-sulphonate (Nilsson et al., 1975). Such binding studies are unlikely to mirror perfectly the binding of $\mathrm{T}_{4}$ to TTR and in vivo the blood concentrations of the hormone are not high enough for the second hormone-binding site to be occupied. $\mathrm{T}_{3}$ and a number of hormone analogues also bind to both sites in mammalian TTR but with a much lower affinity than $\mathrm{T}_{4}$.

\section{Transthyretin and Retinol-Binding Protein Interaction}

TTR also binds retinol-binding protein (RBP), the specific carrier of all-trans-retinol. RBP is a single polypeptide chain of 182 amino acid residues of 21 kDa (Goodman, 1984) that forms a complex with tetrameric TTR under physiological conditions and that prevents glomerular filtration of RBP in the kidney (Kanai et al., 1968; Peterson, 1971). The presence of retinol bound to RBP is essential for the formation of 
a stable complex with TTR and crystallographic studies have established the stoichiometry of the complex as a maximum of two RBP molecules per TTR tetramer (Noy et al., 1992; van Jaarsveld et al., 1973; Monaco et al., 1995). The RBP-TTR complex is proposed to be the physiological circulatory retinol transport complex of humans and other terrestrial vertebrates (Vieira et al., 1995). The elimination of the normal RBP-TTR complex, as occurs in the TTR-null mouse model (Episkopou et al., 1993), or by treatment with fenretinide (Berni and Formelli, 1992), results in a significant reduction in plasma RBP and consequently retinol. Despite low plasma levels of retinol $(<6 \%$ normal) the embryos of TTR-null mice develop normally and have similar viability and fertility to mice carrying the normal TTR gene (Wei et al., 1995). Adult monotremes and Australian polyprotodont marsupials also normally appear to lack plasma TTR, as demonstrated by the absence of $\mathrm{T}_{4}$ binding (Schreiber and Richardson, 1997), but the consequence of this for the maintenance of normal plasma RBP and retinol levels is unclear. Concentrations of RBP and retinol have not been determined in these species and further studies would provide valuable information concerning the role of the retinol-RBP-TTR complex in retinoid transport.

The possibility of RBP-TTR interaction in fish plasma still requires investigation. RBP has been isolated from several fishes (Shidoji and Muto, 1977; Muto et al., 1982) and in rainbow trout (Oncorhynchus mykiss, Berni et al., 1992) it has been shown that despite low sequence conservation (60\% identity) with phylogenetically distant vertebrates, RBP has a similar structural organisation. Moreover, rainbow trout, but not Seriola quinqueradiata, RBP can interact with mammalian TTR (Berni et al., 1992). As such studies were carried out with heterologous TTR their biological significance is unclear.

Comparison of the model of sea bream TTR with the structure in mammals and bird indicates, as noted, that in evolution there has been an overall decrease in negative electrostatic potential (Fig. 4) of the tetramer. However, an effect of the electrostatic potential differences observed in TTR from different vertebrate groups on the binding of RBP is not obvious, since analysis of the contact zone for RBP in mammals, birds, and fish suggests neutral electrostatic characteristics. Moreover, there has been conservation of the shape of this domain between TTR of fish, mammals, and birds. The conservation of these characteristics may explain why trout RBP can interact with mammalian TTR (Berni et al., 1992) and suggests a strong selection pressure to retain the structure of this domain. The biological and evolutionary significance of this conservation remains to be determined.

\section{GENE STRUCTURE OF TRANSTHYRETIN IN MAMMALS, MARSUPIALS, BIRDS, AND LIZARDS}

\section{Genomic Structure}

The genomic structures of TTR have been described in human (Sasaki et al., 1985, 1989), rat (Fung et al., 1988), and mouse (Costa et al., 1986). Human TTR is a single-copy gene, which has been mapped to chromosome 18q11.2-q12.1 (Sparkes et al., 1987), spans $6.9 \mathrm{~kb}$ with four exons, three introns, a TATA box-like sequence at $n t-24-30$ and CAAT box-like sequence at -95-102 (Sasaki et al., 1985; Tsuzuki et al., 1985). The first exon encodes the 5 ' untranslated region and contains an 18-amino-acid signal peptide as well as the first 3 amino acid residues of the mature protein, whilst exon 2 codes for residues $4-47$, exon 3 for residues 47-92, and exon 4 for residues 93-127.

The rat and mouse genes are also composed of four exons, contain a TATA-box and CAAT-box sequence, and have a gene organisation similar to that found in the human. The 5' flanking region of the gene contains a short DNA segment, the -50 to 190 region, which is extremely well conserved (93\%) between human and rodents (Costa et al., 1986; Fung et al., 1988). It has been proposed that this region is important for the cellspecific regulation of the gene and binding sites for HNF-1, C/EBP, HNF-3, HNF-4, and HNF-6 (Costa et al., 1989; Samadani and Costa, 1996). In addition to these, further regulatory elements, at least $2000 \mathrm{bp}$ upstream of the gene, may be involved in the regulation of gene expression in human and mouse liver via both cis-acting and trans-acting factors. Studies with transgenic mice have identified two regions, a 100nucleotide enhancer located $-2 \mathrm{~kb}$ upstream and a proximal -150 to 90 -bp promoter region, sufficient for 
directing TTR expression in the liver (Costa et al., 1989; Yan et al., 1990). Abundant TTR gene expression also occurs in the choroid plexus of mammals, birds, and reptiles, but little is known about the regulatory mechanisms. The genomic organisations for TTR of amphibians and fish have not yet been determined but gene expression is restricted mainly to the liver. Comparative studies between the TTR gene from fish and amphibians and that from eutherians, birds, and lizards may provide a means of identifying elements in the $5^{\prime}$ region that regulate TTR expression in the choroid plexus.

\section{cDNA Structure}

The cDNA for transthyretin has now been cloned from over 10 different species (Schreiber and Richardson, 1997). A single mRNA transcript has been described in all species and transcript size varies from $0.65 \mathrm{~kb}$ in the Australian diprotodont marsupial, sugar glider (Petaurus breviceps, Duan et al., 1995), to $0.7 \mathrm{~kb}$ in rat (Dickson et al., 1985). The cDNA generally consists of a $5^{\prime}$ untranslated region (14-30 nucleotides), a coding region that corresponds to $127-130$ amino acids, and a 3' untranslated region (115-181 nucleotides) preceding the poly $(\mathrm{A})$ tail. The size of the mature protein is 130 amino acids in the pig (Duan et al., 1995); 127 amino acids in the rat (Dickson et al., 1985), human (Mita et al., 1984; Soprano et al., 1985; Wallace et al., 1986), mouse (Wakasugi et al., 1985), and wallaby (Macropus eugenii, Brack et al., 1995); 129 amino acids in short-tailed grey opposum (Monodelphis domestica), stripe-faced dunnart (Sminthopsis macroura), and sugar glider (Duan et al., 1993); and 130 amino acids in the chicken (Duan et al., 1991), lizard (Achen et al., 1993), bullfrog (Yamauchi et al., 1998), and teleost fish (Santos and Power, 1999). Comparison of the amino acid sequence of TTR from mammals and marsupials with TTR from birds, amphibians, and fish demonstrates the presence in the latter species of 3 additional amino acids at the N-terminus, Val-Ser-His in chicken and lizard; Gly-Thr-His in frog, and Asp-Lys-His in fish. Studies of the $5^{\prime}$ organisation of the gene in eutherians and birds suggest that this is the region that has changed most distinctly during evolution. Changes in the splice sites of intron 1 have led to the production of TTR with a shorter more hydrophilic N-terminal amino acid sequence (Aldred et al., 1997); the effect of this alteration on function remains to be determined. However, TH-binding studies with plasma from birds and mammals show that TTR in birds preferentially binds $T_{3}$ while in mammals it preferentially binds $T_{4}$, and it has been suggested that the change in the $\mathrm{N}$ terminal amino acid sequence of TTR may be responsible for the change in hormone affinity (Chang et al., 1999). The longer, more hydrophobic N-termini correlate with preferential binding to $\mathrm{T}_{3}$ and the shorter, more hydrophilic N-termini preferential binding to $\mathrm{T}_{4}$ (Chang et al., 1999, Yamauchi et al., 1999). The relative importance of the molecular electrostatic potential or the nature of the $\mathrm{N}$-terminus on the binding characteristics of TTR is unclear and to date is an unresolved question.

The TTR mRNA encodes a pro-TTR monomer. The $\mathrm{N}$-terminal region is a hydrophobic signal peptide that, depending on the species, consists of up to 20 amino acids (Soprano et al., 1985). Pro-TTR undergoes a cleavage process during its migration through the endoplasmic reticulum membrane to yield the native TTR monomer (Soprano et al., 1985). Multiple alignment of the sequence from representative species reveals the very high conservation that has occurred in this protein (Fig. 2) between eutherians, marsupials, birds, and lizards (85-65\%). The sequence conservation between TTR from the latter species and amphibian and fish is much lower (47-48\% identity, Table 2). However, if the protein sequences from various species are compared considering conservative amino acid substitutions, there is a substantial increase in similarity between sequences, suggesting that the overall chemical properties of the protein have been conserved (see Fig. 2) during its evolution.

\section{Transthyretin Sequence Heterogeneity}

TTR is encoded by a single gene that gives rise to a single protein product. However, in human TTR there is considerable sequence heterogeneity as a consequence of mutations resulting in substitution of a single residue at various positions of the normal amino acid sequence. These mutations may be nonpathogenic or they may cause familial amyloidotic polyneuropathy, an hereditary disease characterised by extracellular deposition of transthyretin-derived amyloid 
in various tissues (peripheral nervous system, heart, vitreous body of the eye); see reviews by Sipe (1992); Benson and Uemichi (1996); Ingenbleek and Young (1994), and Schreiber and Richardson (1997). Several mutation "hotspots" have been postulated within the coding sequence of TTR (Gly6Ser, Val30Met, Arg104Cys, Ala109Thr, Thr119Met, Val122Ile, residue position in the mature protein after removal of the 20-residue prepeptide), although most mutations identified so far are not associated with these hotspots and are evenly distributed along the molecule.

Comparison of the primary sequence of TTR from different vertebrate species with that of human variants demonstrates that some of the mutations that cause disease in human are a normal feature of the protein in other species. For example, the mutations identified in human TTR that lead to the substitution of Val30Leu and Ile84Ser are normally present in sea bream TTR and Ile68Leu occurs in skink TTR (Fig. 2). Comparison of human TTR variants associated with pathology with TTR from other species demonstrates that 15 of the 36 substituted amino acids in human TTR have been $100 \%$ conserved in TTR of all other species, suggesting that there has been strong evolutionary pressure to conserve these residues probably because they are of structural or functional importance. The remaining 21 amino acids known to be altered in human TTR variants show little conservation between species. It will be of interest to determine why these TTR variants cause disease in humans but similar amino acid substitutions have no obvious effect in other species where they appear to have arisen normally as a consequence of evolution.

The consequence of amino acid substitutions in TTR is clearly complex and analysis of the primary structure alone may be insufficient to understand the consequences of a certain residue change, particularly since other residues in its structural vicinity may have been substituted simultaneously, compensating for the instability introduced by one mutation alone. The overall effects of particular amino acid substitutions may vary depending upon several factors, including ionisation state of amino acid functional groups and $\mathrm{pH}$ of the immediate environment within the molecule as well as the metabolic and physiological differences between species.

\section{TRANSTHYRETIN GENE EXPRESSION}

TTR has a fairly restricted gene expression, being demonstrated principally in the liver and choroid plexus of rat (Dickson et al., 1985; Fung et al., 1988; Schreiber et al., 1990), human (Dickson and Schreiber, 1986), sheep (Schreiber et al., 1990), pig (Duan et al., 1995), and chicken (Southwell et al., 1991) and in the liver of marsupials (Richardson et al., 1994). In two reptiles, the turtle (Trachemys scripta) and lizard (Tiliqua rugosa), TTR is present in the brain but little or no expression has been detected in the liver (Achen et al., 1993; Richardson et al., 1997). The protein synthesised in the liver is secreted into the blood, whilst from the choroid plexus epithelium it is secreted into the cerebrospinal fluid, presumably to carry essential $\mathrm{TH}$ to the brain (Dickson et al., 1987). TTR expression has been detected in the eye of cattle and sheep (Cavallaro et al., 1990; Dwork et al., 1990; Martone, 1988) and in vitro cultures of pigment epithelium of the retina from the rat show synthesis and secretion of TTR into the interphotoreceptor space of the retina (Ong et al., 1994). Low levels of TTR mRNA are also expressed in the rat and human pancreas (Jacobsson et al., 1990). TTR is also reported to be present in the visceral yolk sac during fetal rat development (Soprano et al., 1986), in the developing rat eye (Mizuno et al., 1992), and in developing chicken heart (Barron et al., 1998) although its function during development remains to be determined.

In premetamorphic tadpoles of frog, TTR is expressed principally in the liver and has not been detected in choroid plexus where lipocalcin is the main protein synthesised (Achen et al., 1992). In juvenile sea bream TTR is expressed principally in the liver and appears to be absent from the choroid plexus (Santos and Power, 1999). Northern blot studies with a range of adult sea bream tissues have demonstrated that, in addition to abundant expression in the liver, it was possible to detect significant TTR expression in the intestine and heart (Fig. 5), raising questions about its physiological function at these sites. The different locations of TTR gene expression suggest evolutionary variations and adaptations in TTR function. 


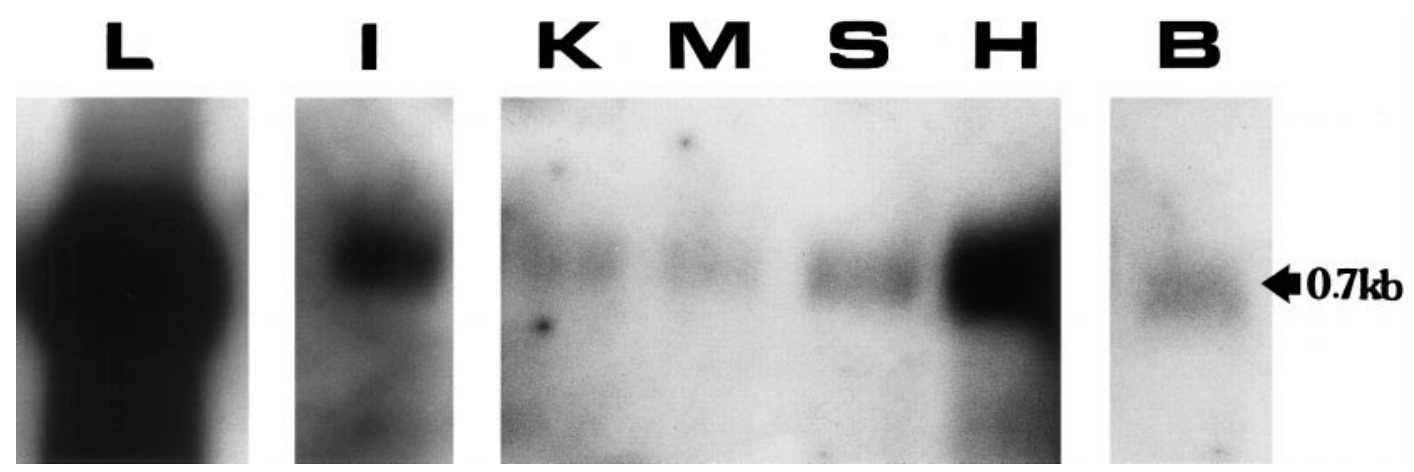

FIG . 5. Northern blot analysis of the expression of TTR in adult sea bream tissues. L, liver; I, intestine; K, kidney; M, muscle; S, skin; H, heart; $\mathrm{B}$, brain. $10 \mu \mathrm{g}$ of RNA poly(A) ${ }^{+}$from each tissue was loaded on a $2.2 \%$ formaldehyde $/ 1.1 \%$ agarose gel, transferred to a nylon membrane, and fixed by UV crosslinking. This membrane was hybridised at $55^{\circ} \mathrm{C}$ overnight with a full-length sea bream TTR cDNA probe labelled with $\left[\alpha-{ }^{32} \mathrm{P}\right] \mathrm{dCTP}$. The filter was washed using high-stringency conditions and exposed to Kodak X-OMAT with intensifying screens at $-70^{\circ} \mathrm{C}$ for $12 \mathrm{~h}$ (liver) and $48 \mathrm{~h}$ (intestine, kidney, muscle, skin, heart, and brain). A single transcript, $0.7 \mathrm{~kb}$, of varying intensity was detected in all tissues analysed. Liver had the highest expression of TTR, but in the sea bream a strong signal was also detected in intestine and heart.

\section{EVOLUTION OF TRANSTHYRETIN}

Existing models of TTR evolution are largely based on results of binding studies of radiolabelled $\mathrm{T}_{4}$ with blood plasma from adult representatives of most vertebrate groups, of SDS-PAGE of the secretory products from the choroid plexus, or of Northern blotting of various tissues (Harms et al., 1991; Richardson et al., 1994; Schreiber et al., 1993). Such studies demonstrated $\mathrm{T}_{4}$ binding to TTR in the plasma of all birds, eutherian mammals, and adult diprotodont marsupials (which includes kangeroos and opossums) and the absence of such binding in monotremes, polyprotodont marsupials, reptiles, amphibians, and fish (Chang et al., 1999; Richardson et al., 1994, 1997; Schreiber and Richardson, 1997). In common with other plasma proteins TTR is expressed and secreted by the liver (Schreiber, 1987) and its expression at this site in homeotherms is proposed to have occurred independently in birds, eutherians, and diprotodont marsupials (Richardson et al., 1994; Schreiber et al., 1993, 1995). The other main site of TTR gene expression in reptiles, birds, eutherians is the choroid plexus (Achen et al., 1993) where it is the only thyroid hormone-binding protein synthesised (Schreiber, 1987), and TTR is presumed to facilitate the transport of $\mathrm{TH}$ into the brain.

Strong expression of TTR in the choroid plexus but not in the liver of the stumpy-tailed lizard (Achen et al., 1993), together with the strong conservation of TTR in the choroid plexus from reptiles to mammals
(Harms et al., 1991), and the apparent absence from amphibians and fish, on the basis of ligand-binding studies with plasma from adults, led to the hypothesis that the expression of the TTR gene first arose in the brain of reptiles (Achen et al., 1993); it subsequently and independently arose in the liver of birds, eutherians, and diprotodont marsupials. However, the cloning and characterisation of TTR from the liver of premetamorphic amphibians and juvenile fish (Santos and Power, 1996, 1999; Yamauchi, 1998) indicate that the gene for TTR probably arose in or prior to the ancient fishes. The presence in amphibians and fish of gene expression for TTR in the liver and its absence from the choroid plexus suggest that indeed TTR expression in the brain first arose in the reptiles, but that this evolved subsequent to its expression in the brain first arose in the reptiles, but that this evolved subsequent to its expression in the liver. The selection pressure for "turning on" TTR gene expression in the brain may be the rapid evolution of the brain and its concomitant increase in size and complexity, with the first traces of a neocortex appearing in the stem reptiles (Duan et al., 1995, Richardson et al., 1997). TTR, it is proposed, would function to ensure appropriate extracellular and intracellular thyroid hormone distribution in the brain (Schreiber and Richardson, 1997).

In addition to evolution of differential tissue expression of TTR, there appears to have been a change in function from a $\mathrm{T}_{3}$ transporter to a $\mathrm{T}_{4}$ transporter (Chang et al., 1999; Yamauchi et al., 1999). The phylo- 


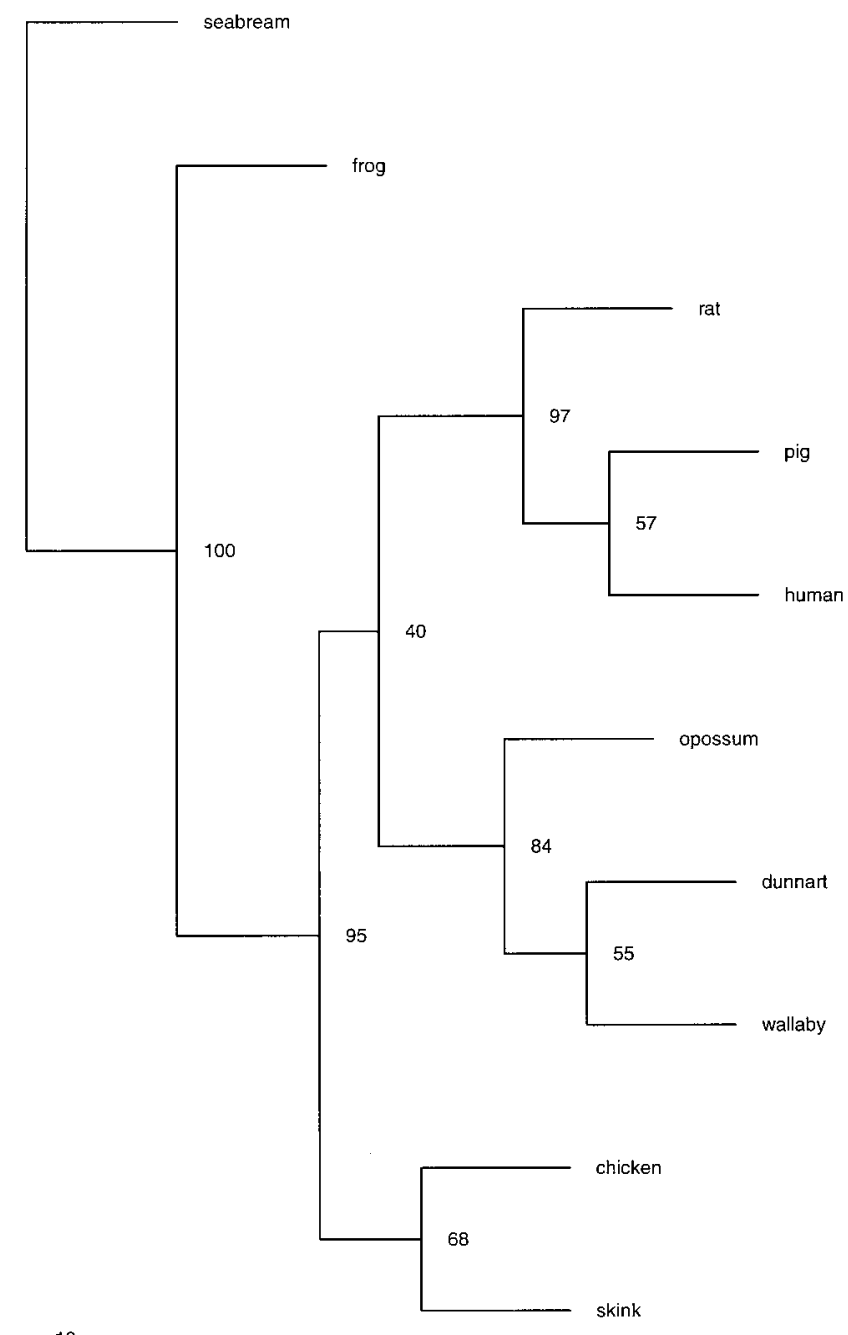

$-10$

FIG. 6. Phylogram generated by Clustal X (Gibson et al., 1994) of representative species from eutherians mammals-human (Sasaki et al., 1985), pig (Sus scorfa, Duan et al., 1995), and rat (Rattus norvegicus, Dickson et al., 1985); marsupial mammals-dunnart (Sminthopsis macroura, Duan et al., 1995) (Australian Polyprotodonta), wallaby (Macropus eugenii, Brack et al., 1995) (Australian Dyprotodonta), and opossum (Monodelphis domestica, Duan et al., 1995) (American Polyprotodonta); birds_chicken (Gallus gallus, Duan et al., 1991); reptile-skink (Tiliqua rugosa, Achen et al., 1993); amphibian-frog (Rana catesbeiana, Yamauchi et al., 1998); and fish—sea bream (Sparus aurata, Santos and Power, 1999).

gram of TTR (Fig. 6) from representatives of each of the classes from which it has been isolated and sequenced corresponds approximately to the phylogenetic tree for the evolution of vertebrates. Interestingly the TTR from eutherian and marsupial mammals that have the highest affinity for $\mathrm{T}_{4}$ are clustered into a group separate from TTR from birds, reptiles, amphibians, and fish. The functional significance of the change in affinity of TTR for TH is unclear but may be related to differences in thyroid hormone balance and metabolism; there are reports of higher blood levels of $\mathrm{T}_{3}$ than $\mathrm{T}_{4}$ in murine fish (Bjornsson et al., 1998; Eales and Shostak, 1987; Pavlidis et al., 1997), in contrast to mammals, in which $\mathrm{T}_{4}$ predominates (McNabb, 1992). This is an area of thyroid hormone physiology that clearly merits further attention.

\section{REFERENCES}

Achen, M. G., Duan, W., Pettersson, T. M., Harms, P. J., Richardson, S. J., Lawrence, M. C., Wettenhall, R. E. H., Aldred, A. R., and Schreiber, G. (1993). Transthyretin gene expression in choroid plexus first evolved in reptiles. Am. J. Physiol. 265, R982-R989.

Achen, M. G., Harms, P. J., Thomas, T., Richardson, S. J., Wettenhall, R. E. H., and Schreiber, G. (1992). Protein synthesis at the bloodbrain barrier: The major protein secreted by amphibian choroid plexus is a lipocalcin. J. Biol. Chem. 267, 23170-23174.

Aldred, A. R., Prapunpoj, P., and Schreiber, G. (1997). Evolution of a shorter and more hydrophilic transthyretin N-termini by stepwise conversion of exon 2 into intron 1 sequences (shifting the $3^{\prime}$ splice site of intron 1). Eur. J. Biochem. 246, 401-419.

Andrea, T. A., Cavalieri, R. R., Goldfine, I. D., and Jorgensen, E. C. (1980). Binding of thyroid hormones and analogues to the human plasma protein prealbumin. Biochemistry 19, 55-63.

Barrington, E. J. W. (1962). Hormones and vertebrate evolution. Experientia 18, 201-210.

Barron, M., McAllister, D., Smith, S. M., and Lough, J. (1998). Expression of retinol binding protein and transthyretin during early embryogenesis. Dev. Dyn. 212, 413-422.

Benson, M. D., and Uemichi, T. (1996). Transthyretin amyloidosis. Int. J. Exp. Clin. Invest. 3, 44-56.

Bentley, P. J. (1998). “Comparative Vertebrate Endocrinology," pp. 28-32. Cambridge Univ. Press, London.

Berni, R., and Formelli, F. (1992). In vitro interaction of fenretinide with retinol-binding protein and its functional consequences. FEBS Lett. 308, 43-45.

Berni, R., Stoppini, M., and Zapponi, M. C. (1992). The piscine plasma retinol-binding protein. Eur. J. Biochem. 204, 99-106.

Bjornsson, B. Th., Halldorsson, O., Haux, C., Norberg, B., and Brown, C. L. (1998). Photoperiod control of sexual maturation of the Atlantic halibut (Hippoglossus hippoglossus): Plasma thyroid hormone and calcium levels. Aquaculture 166, 117-140.

Blake, C. C. F., Geisow, M. J., Oatley, S. J., Rerat, B., and Rérat, C. (1978). Structure of prealbumin: Secondary, tertiary and quaternary interactions determined by Fourier refinement at $180 \mathrm{pm}$. J. Mol. Biol. 121, 339-356. 
Blake, C. C. F., Geisow, M. J., and Swan, I. D. A. (1974). Structure of human plasma prealbumin at 2.5 AA resolution. J. Mol. Biol. 88, $1-12$.

Blake, C. C. F., and Oatley, S. J. (1977). Protein-DNA and proteinhormone interactions in prealbumin: A model of the thyroid hormone nuclear receptor. Nature 268, 115-120.

Brack, C. M., Duan, W., Hulbert, A. J., and Schreiber, G. (1995). Wallaby transthyretin. Comp. Biochem. Physiol. 110B, 523-529.

Burke, D. F., Deane, C. M., Nagarajaram, H. A., Campillo, N., Martin-Martinez, M., Mendes, J., Molina, F., Perry, J., Reddy, B. V. B., Soares, C. M., Steward, R. E., Williams, M., Carroudo, M. A., Blundell, T. L., and Mizuguchi, K. (1999). An iterative structure-assisted approach to sequence alignment and comparative modelling. Proteins Suppl. 3, 55-60.

Cavallaro, T., Martone, R. L., Dwork, A. J., Schon, E. A., and Herbert, J. (1990). The retinal epithelium is the unique site of transthyretin synthesis in the rat eye. Invest. Ophthal. Vis. Sci. 31, 497501.

Chang, L., Munro, S. L. A., Richardson, S. J., and Schreiber, G. (1999). Evolution of thyroid binding in transthyretins in birds and mammals. Eur. J. Biochem. 259, 534-542.

Cheng, S. Y., Pages, R. A., Saroff, H. A., Edelhoch, H., and Robbins, J. (1977). Analysis of thyroid hormone binding to human serum prealbumin by 8 -anilinonaphthalene-1-sulfonate fluorescence. Biochemistry 16, 3707-3713.

Costa, R. H., Grayson, D. R., and Darnell, J. E. (1989). Multiple hepatocyte-enriched nuclear factors function in the regulation of transthyretin and $\alpha_{1}$-antitrypsin genes. Mol. Cell. Biol. 9, 14151425.

Costa, R. H., Lai, E., and Darnell, J. E. (1986). Transcriptional control of the mouse prealbumin (transthyretin) gene: Both promoter sequences and a distinct enhancer are cell specific. Mol. Cell. Biol. 6, 4697-4708.

Darras, V. M., Mol, K. A., van de Geyten, S., and Kuhn, E. R. (1998). Control of peripheral thyroid hormone levels by activating and inactivating deiodinases. Ann. N. Y. Acad. Sci. 839, 80-86.

de la Paz, P., Burridge, J. M., Oatley, S. J., and Blake, C. C. F. (1992). Multiple modes of binding of thyroid hormones and other iodothyronines to human plasma transthyretin. In "The Design of Drugs to Macromolecular Targets" (C. R. Beddell, Ed.), pp. 119172. Wiley, Brisbane.

Dickson, P. W., Aldred, A. R., Marley, P. D., Guo-Fen, T., Howlett, G. J., and Schreiber, G. (1985). High prealbumin and transferrin mRNA levels in the choroid plexus of rat brain. Biochem. Biophys. Res. Commun. 127, 890-895.

Dickson, P. W., Aldred, A. R., Menting, J. G. T., Marley, P. D., Sawyer, W. H., and Schreiber, G. (1987). Thyroxine transport in choriod plexus. J. Biol. Chem. 262, 13907-13915.

Dickson, P. W., Howlett, G. J., and Schreiber, G. (1985). Rat transthyretin (prealbumin). J. Biol. Chem. 260, 8214-8219.

Dickson, P. W., and Schreiber, G. (1986). High levels of messenger RNA for transthyretin (prealbumin) in human choroid plexus. Neurosci. Lett. 66, 311-315.

Duan, W., Achen, M. G., Richardson, S. J., Lawrence, M. C., Wettenhall, R. E. H., Jaworowski, A., and Schreiber, G. (1991). Isola- tion, characterisation, cDNA cloning and gene expression of an avian transthyretin. Eur. J. Biochem. 200, 679-687.

Duan, W., Richardson, S. J., Babon, J. J., Heyes, R. J., Southwell, B. R., Harms, P. J., Wettenhall, R. E. H., Dziegielewska, K. M., Selwood, L., Bradley, A. J., Brack, C. M., and Schreiber, G. (1993). Evolution of transthyretin in marsupials. J. Biol. Chem. 268, 2416-2424.

Duan, W., Richardson, S. J., Kohrle, J., Chang, L., Southwell, B. R., Harms, P. J., Brack, C. M., Pettersson, T. M., and Schreiber, G. (1995). Binding of thyroxine to pig transthyretin, its cDNA structure, and other properties. Eur. J. Biochem. 230, 977-986.

Dunn, A. D. (1980). Studies on iodoproteins and thyroid hormones in Ascidians. Gen. Comp. Endocrinol. 40, 473-483.

Dwork, A. J., Cavallaro, T., Martone, R. L., Goodman, D. S., Schon, E. A., and Herbert, J. (1990). Distribution of transthyretin in the rat eye. Invest. Ophthalmol. Vis. Sci. 31, 489-496.

Eales, J. G. (1985). The peripheral metabolism of thyroid hormones and regulation of thyroidal status in poikilotherms. Can. J. Zool. 63, 1217-1231.

Eales, J. G., and Shostak, S. (1987). Total and free thyroid hormones in plasma of tropical marine teleost fish. Fish Physiol. Biochem. 3, 127-131.

Episkopou, V., Maeda, S., Nishiguchi, S., Shimada, K., Gaitanaris, G. A., Gottesman, M. E., and Robertson, E. J. (1993). Disruption of the transthyretin gene results in mice with depressed levels of plasma retinol and thyroid hormone. Proc. Natl. Acad. Sci. USA 90, 2375-2379.

Fung, W-P., Thomas, T., Dickson, P. W., Aldred, A. R., Milland, J., Dziadek, M., Power, B., Hudson, P., and Schreiber, G. (1988). Structure and gene expression of rat transthyretin (prealbumin) gene. J. Biol. Chem. 263, 480-488.

Gibson, T., Higgins, D., and Thompson, J. (1994). Clustal X. EMBL, Heidelberg, Germany.

Goodman, D. S. (1984). Vitamin A and retinoids in health and disease. N. Engl. J. Med. 310, 1023-1031.

Gorbman, A., Dickhoff, W. W., Vigna, S. R., Clark, N. B., and Ralph, C. L. (1983). "Comparative Endocrinology" pp. 185-275. Wiley, New York.

Hamilton, J., Steinrauf, L., Braden, B., Liepnieks, J., Benson, M., Holmgren, G., Sandgren, O., and Steen, L. (1993). The X-ray crystal structure refinement of normal human transthyretin and the amiloidogenic Val30-Met variant to $1.7 \AA$ A resolution. J. Biol. Chem. 268, 2416-2424.

Harms, P. J., Tu, G. F., Richardson, S. J., Aldred, A. R., Jaworowski, A., and Schreiber, G. (1991). Transthyretin (prealbumin) gene expression in choroid plexus is strongly conserved during evolution of vertebrates. Comp. Biochem. Physiol. 99B, 239-249.

Hillier, A. P. (1970). The binding of thyroid hormones to phospholipid membranes. J. Physiol. 211, 585-597.

Ingenbleek, Y., and Young, V. (1994). Transthyretin (prealbumin) in health and disease: Nutritional implications. Annu. Rev. Nutr. 14, 495-533.

Jacobsson, B., Carlstrom, A., Platz, A., and Collins, V. P. (1990). Transthyretin messenger ribonucleic acid expression in the pancreas and in endocrine tumours of the pancreas and gut. J. Clin. Endocrinol. Metab. 71, 875-880. 
Kanai, M., Raz, A., and Goodman, D. S. (1968). Retinol-binding protein: The transport protein for vitamin A in human plasma. J. Clin. Invest. 47, 2025-2044.

Kraulis, P. J. (1991). MOLSCRIPT: A program to produce both detailed and schematic plots of protein structures. J. Appl. Crystallogr. 24, 946-950.

Larsson, M., Petterson, T., and Carlstrom, A. (1985). Thyroid-hormone binding in the serum of 15 vertebrate species: Isolation of thyroxine binding globulin and prealbumin analogs. Gen. Comp. Endocrinol. 58, 360-375.

Laskowski, A., MacArthur, M., Moss, D., and Thorton, J. (1993). PROCHECK: A program to check the stereochemical quality of protein structures. J. Appl. Crystallogr. 26, 283-291.

Leonard, J. L., and Visser, T. J. (1986). Biochemistry of deiodination. In "Thyroid Hormone Metabolism" (G. Hennemann, Ed.), pp. 189-229. Dekker, New York.

Martone, R. L., Herbert, J., Dwork, A., and Schon, E. A. (1988). Transthyretin is synthesized in the mammalian eye. Biochim. Biophys. Res. Commun. 151, 905-912.

McNabb, F. M. A. (1992). "Thyroid Hormones." Prentice-Hall, Englewood Cliffs, NJ.

Mendel, C. M., and Weisiger, R. A. (1990). Thyroxine uptake by perfused rat liver. No evidence for facilitation by five different thyroxine-binding proteins. J. Clin. Invest. 86, 1840-1847.

Mendel, C. M., Weisiger, R. A., Jones, A. L., and Cavalieri, R. R. (1987). Thyroid hormone-binding proteins in plasma facilitate uniform distribution of thyroxine within tissues: A perfused rat liver study. Endocrinology 120, 1742-1749.

Mendes, J., Baptista, A. M., Carrondo, M. A., and Soares, C. M. (1999a). Improved modelling of side chains in proteins with rotamer-based methods: A flexible rotamer model. Proteins 37, 530543.

Mendes, J., Soares, C. M., and Carrondo, M. A. (1999b). Improvement of side-chain modelling in proteins with the self-consistent mean field theory method based on an analysis of the factors influencing prediction. Biopolymers 50, 111-131.

Merritt, E. A., and Bacon, D. J. (1997). Raster3D photorealistic molecular graphics. Methods Enzymol. 277, 505-524.

Mita, S., Maeda, S., Shimada, K., and Araki, S. (1984). Cloning and sequence analysis of cDNA for human prealbumin. Biochem. Biophys. Res. Commun. 124, 558-564.

Mizuno, R., Cavallaro, T., and Herbert, J. (1992). Temporal expression of the transthyretin gene in the developing rat eye. Invest. Ophthalmol. Vis. Sci. 33, 341-349.

Monaco, F., Dominici, R., Andreoli, M., de Pirro, R., and Roche, J. (1981). Thyroid hormone formation in thyroglobulin synthesized in the amphioxus (Branchiostoma lanceolatum PALLAS). Comp. Biochem. Physiol. B70, 341-343.

Monaco, H. L., Rizzi, M., and Coda, A. (1995). Structure of a complex of two plasma proteins: Transthyretin and retinol-binding protein. Science 268, 1039-1041.

Muto, Y., Shidoji, Y., and Kanda, Y. (1982). Isolation and characterization of serum retinol-binding protein. Methods Enzymol. 81, $840-852$.

Nicholls, A. (1992). GRASP: Graphical Representation and Analysis of Surface Properties. Columbia University, New York.
Nilsson, S., and Peterson, P. (1971). Evidence for multiple thyroxinebinding sites in human prealbumin. J. Biol. Chem. 246, 6098-6105.

Nilsson, S. F., Rask, L., and Peterson, P. A. (1975). Studies on thyroid hormone-binding proteins. II. Binding of thyroid hormones, retinol-binding protein, and fluorescent probes to prealbumin and effects of thyroxine on prealbumin subunit self association. J. Biol. Chem. 250, 8554-8563.

Noy, N., Slosberg, E., and Scarlata, S. (1992). Interactions of retinol with binding proteins: Studies with retinol binding protein and with transthyretin. Biochemistry 31, 11118-11124.

Ong, D. E., Davis, J. T., O’Day, W. T., and Bok, D. (1994). Synthesis and secretion of retinol-binding protein and transthyretin by cultured retinal pigment epithelium. Biochemistry 33, 1835-1842.

Pavlidis, M., Berry, M., Divanach, P., and Kentouri, M. (1997). Diel patterns of haematocrit, serum metabolites, osmotic pressure, electrolytes and thyroid hormones in sea bass and sea bream. Aquaculture Int. 5, 237-247.

Peterson, P. A. (1971). Studies on the interaction between prealbumin, retinol-binding protein, and vitamin A. J. Biol. Chem. 246, 44-49.

Richardson, S. J., Bradley, A. J., Duan, W., Wettenhall, R. E. H., Harms, P. J., Babon, J. J., Southwall, B. R., Nicol, S., Donnellan, S. C., and Schreiber, G. (1994). Evolution of marsupial and other vertebrate thyroxine-binding plasma proteins. Am. J. Physiol. 266, R1359-R1370.

Richardson, S. J., Hunt, J. L., Aldred, A. R., Licht, P., and Schreiber, G. (1997). Abundant synthesis of transthyretin in the brain but not in the liver, of turtles. Comp. Biochem. Physiol. 117, 421-429.

Robbins, J. (1975). In "Thyroid Hormone Metabolism" (W. E. Harland and J. S. Orr, Eds.), pp. 1-22. Academic Press, New York.

Robbins, J., and Edelhoch, H. (1986). Thyroid hormone transport proteins: Their nature, biosynthesis, and metabolism. In "Werner's The Thyroid" (S. H. Ingbar and L. E. Braverman, Eds.), 5th ed., pp. 116-127. Lippincott, Philadelphia.

Sali, A., and Blundell, T. L. (1993). Comparative protein modelling by satisfaction of spacial restraints. J. Mol. Biol. 234, 779-815.

Samadani, U., and Costa, R. H. (1996). The transcriptional activator hepatocyte nuclear factor 6 regulates liver gene expression. Mol. Cell. Biol. 16, 6273-6284.

Santos, C. R. A., and Power, D. M. (1996). Piscine (Sparus aurata) transthyretin. Ann. Endocrinol. 57, 58.

Santos, C. R. A., and Power, D. M. (1999). Identification of transthyretin in fish (Sparus aurata): cDNA cloning, and characterization. Endocrinology 140, 2430-2433.

Sasaki, H., Yoshioka, N., Takagi, Y., and Sasaki, Y. (1985). Structure of the chromosomal gene for human serum prealbumin. Gene 37, 191-197.

Sasaki, Y., Yoshioka, K., Tanahashi, H., Furuya, H., and Sasaki, H. (1989). Human transthyretin (prealbumin) gene and molecular genetics of familial amyloidotic polyneuropathy. Mol. Biol. Med.6, 161-168.

Schreiber, G. (1987). Synthesis, processing and secretion of plasma proteins by the liver and other organs and their regulation. In “The Plasma Proteins" (F. W. Putnam, Ed.), 2nd ed. pp. 293-363. Academic Press, New York. 
Schreiber, G., Aldred, A. R., Jaworowski, A., Nilsson, C., Achen, M. G., and Segal, M. B. (1990). Thyroxine transport from blood to brain via transthyretin synthesis in choroid plexus. Am. J. Physiol. 258, R338-R345.

Schreiber, G., Pettersson, T. M., Southwall, B. R., Aldred, A. R., Harms, P. J., Richardson, S. J., Wettenhall, R. E. H., Duan, W., and Nicoll, S. C. (1993). Transthyretin expression evolved more recently in liver than in brain. Comp. Biochem. Physiol. 105B, 317-325.

Schreiber, G., and Richardson, S. (1997). The evolution of gene expression, structure and function of transthyretin. Comp. Biochem. Physiol. 116B, 137-160.

Schreiber, G., Southwell, B. R., and Richardson, S. J. (1995). Hormone delivery system to the brain-Transthyretin. Exp. Clin. Endocrinol. 103, 75-80.

Shidoji, Y., and Muto, Y. (1977). Vitamin A transport in plasma of the non-mammalian vertebrates: Isolation and partial characterization of piscine retinol-binding protein. J. Lipid Res. 18, 679-691. Sipe, J. D. (1992). Amyloidosis. Annu. Rev. Biochem. 61, 947-975.

Snyder, S. M., Cavalieri, R. R., Golafine, I. D., Ingbar, S. H., and Jorgensen, E. C. (1976). Binding of thyroid hormones and their analogues to thyroxine-binding globulin in human serum. J. Biol. Chem. 251, 6489-6494.

Soprano, D. R., Herbert, J., Soprano, K., Schon, E. A., and Goodman, D. S. (1985). Demonstration of transthyretin mRNA in brain and other extrahepatic tissues in the rat. J. Biol. Chem. 260, 1179311798 .

Soprano, D. R., Soprano, K. J., and Goodman, D. S. (1986). Retinol binding protein and transthyretin mRNA levels in visceral yolk sac and liver during fetal development in the rat. Proc. Natl. Acad. Sci. USA 83, 7330-7334.

Southwell, B. R., Duan, W., Tu, G-F., and Schreiber, G. (1991). Ontogenesis of transthyretin gene expression in chicken choroid plexus and liver. Comp. Biochem. Physiol. 100B, 329-338.

Sparkes, R. S., Sasaki, H., Mohandas, T., Yoshioka, K., Klisak, I., Sakaki, Y., Heinzmann, C., and Simon, M. (1987). Assignment of the prealbumin (PALB) gene (familial amyloidotic polyneuropathy) to human chromosome region 18q11.2-q12.1. Hum. Genet. 75, 151-154.

Sterling, K. (1964). Molecular structure of thyroxine in relation to its binding by human serum albumin. J. Clin. Invest. 43, 1721-1729.

Sunde, M., Richardson, S. J., Chang, L., Pettersson, T. M., Schreiber, G., and Blake, C. C. F. (1996). The crystal structure of transthyretin from chicken. Eur. J. Biochem. 236, 491-499.

Tanabe, Y., Ishii, T., and Tamaki, Y. (1969). Comparison of thyroxine-binding plasma proteins of various vertebrates and their evolutionary aspects. Gen. Comp. Endocrinol. 13, 14-21.
Thorndyke, M. C. (1978). Evidence for a "mammalian" thyroglobulin in endostyle of the ascidian Stylea clava. Nature 271, 61-62.

Tsuzuki, T., Mita, S., Maeda, S., Araki, S., and Shimada, K. (1985). Structure of the human prealbumin gene. J. Biol. Chem. 260, 557-561.

van Jaarsveld, P. P., Edelhoch, H., Goodman, D. S., and Robbins, J. (1973). The interaction of human plasma retinol-binding protein and prealbumin. Biol. Chem. 248, 4698-4705.

Vieira, A. V., Schneider, W. J., and Vieira, P. M. (1995). Retinoids: Transport, metabolism, and mechanisms of action. J. Endocrinol. 146, 201-207.

Wakasugi, S., Maeda, S., Shimada, K., Nakashima, H., and Migita, S. (1985). Structural comparisons between mouse and human prealbumin. J. Biochem. 98, 1707-1714.

Wallace, M. R., Naylor, S., Kluve-Beckerman, B., Long, G. L., McDonald, L., et al. (1986). Localisation of the human prealbumin gene to chromosome 18. Biochem. Biophys. Res. Commun. 129, 753-758.

Wei, S. H., Episkopou, V., Piantedosi, R., Maeda, S., Shimada, K., Gottesman, M. E., and Blaner, W. S. (1995). Studies on the metabolism of retinol and retinol-binding protein in transthyretin-deficient mice produced by homologous recombination. J. Biol. Chem. 270, 866-870.

Wojtczak, A. (1997). Crystal structure of rat transthyretin at $2.5 \AA \AA A$ resolution: First report on a unique tetrameric structure. Acta Biochim. Pol. 44, 505-517.

Wojtczak, A., Luft, J., and Cody, V. (1992). Mechanism of molecular recognition. Structural aspects of 3,3'-diiodo-l-thyronine binding to human serum transthyretin. J. Biol. Chem. 267, 353-357.

Yamauchi, K., Kasahara, T., Hayashi, H., and Horiuchi, R. (1993). Purification and characterization of a 3,5,3'-I -triiodothyroninespecific binding protein from bullfrog tadpole plasma: A homolog of mammalian transthyretin. Endocrinology 132, 22542261.

Yamauchi, K., Nakajima, J. I., Hayashi, H., and Hara, A. (1999). Purification and characterization of thyroid hormone binding protein from masu salmon serum: A homolog of higher-vertebrate transthyretin. Eur. J. Biochem. 265, 944-949.

Yamauchi, K., Takeuchi, H-A., Overall, M., Dziadek, M., Munro, S. L. A., and Schreiber, G. (1998). Structural characteristics of bullfrog (Rana catesbeiana) transthyretin and its cDNA. Eur. J. Biochem. 256, 287-296.

Yan, C., Costa, R. H., Darnell, J., Chen, J. D., and Van Dyke (1990). Distinct positive and negative elements control the limited hepatocyte and choroid plexus expression of transthyretin in transgenic mice. EMBO J. 9, 869-878. 